\title{
Improving Vocabulary Achievement of Young Learners Using Animated Video
}

\author{
Syarifudin ${ }^{* 1}$, Muhammad ${ }^{2}$ \\ ${ }^{1,2}$ Universitas Islam Negeri Mataram, Mataram, Indonesia \\ email: ${ }^{* 1}$ syarif@uinmataram.ac.id
}

\begin{abstract}
This study aims at finding out whether or not the use of video improves the learners' vocabulary of the young learners. This study applied preexperimental method with one group pre-test and post-test design. Twenty junior high school learners in Mataram involved in this study. The data were collected through vocabulary test (pre-test and post-test). This study used cluster random sampling technique. A t-test was used to measure the significance of animated video usage in improving young learners' vocabulary achievement. Mean score of post-test was greater than the mean score of the pre-test. This study revealed that using animated video can improve learners' vocabulary of the young learners.
\end{abstract}

Keywords_Vocabulary; animated video; young learners

\section{INTRODUCTION}

Language is the furthermost prominence portion of a human being and public process that has numerous functions to get done the life. It consents societies to express their thought, feelings idea and to communicate with others, either in a spoken or written form. This action can be done in four language skills; they are listening, speaking, reading and writing [1]. Vocabulary learning is dominant to language acquisition whether the language is as first, second or foreign language [2]. Vocabulary is essential for the four language skills because communication cannot run well without vocabulary. The listener find difficulties in understanding the message sent by the speaker if they do not have sufficient vocabulary and the speakers get problems to arrange their idea into a proper sentence if they have limited vocabulary.

Being the obligatory subject at school, English necessities severe handling to give the best quality of treatment to the learners. Learning vocabulary is primarily needed to improve language skills. It is a fundamental aspect of language acquisition. In this case, the learners have to know the basic words which are essential to their field of study. Without having an adequate vocabulary, the learners will get difficulties in learning English. It means learning vocabulary; the learners will produce many sentences easily either in spoken or written form. They can also communicate with other people fluently and express their opinion or ideas conveniently. Thus, vocabulary should be the priority in English language teaching and learning.

This study aims at finding out the media to help the learners improve their vocabulary and make them engaging in learning vocabulary. There are

IJoASER, Volume 1, Issue 1, March 2018

DOI: 10.33648 /ijoaser.v1i1.5

Copyright: STAI Al-Furqan Makassar,Indonesia

Content License: CC-BY-SA 
various media used for teaching English which could make the learners feel interested in the learning process and enjoy it, such as using pictures, the sound of music, English songs, English movie, video, etc. However, this study is focusing on using animated video to improve vocabulary achievement of the young learners. Videos are characterized by audio-visual media [3]. It is called audiovisual because the video has pictures and sound that can be seen and heard. The video is noticed as one of the good media that can increase the comprehension of learners study progress. With audiovisual as a media of literature, it can be used as a magnetism tool of learners' attention.

Many language teachers and researchers have reported their studies to explore and expose English teaching learning process by using various strategies, technique, method, and approaches. They carry out to create a more effective teaching-learning process and to give the learners more opportunities to practice their English in the classroom, especially to improve their vocabulary. Insufficient vocabulary is leading to ineffective way to increase the learners' vocabulary mastery because the learners were bored and scared to study English, they were not interested in their lesson, their grammatical knowledge was still low, and their ability to arrange sentence was poor.

An investigation on the effectiveness of using video in teaching listening of oral narrative text (an experimental study) found that video is sufficient to be applied in teaching listening of oral narrative text for the junior high school learners [4]. Animated video is highly effective in developing the learners' levels of vocabulary in the experimental group compared to control groups' results [5]. The animation is moving text and pictures or merely exciting transitions between visual tableaus which can be a useful attention grabber, which lays the necessary foundation for learning. Animation as art or technique of producing images on a surface usually paper using marks in graphite ink, chalk choral or cartoon. It is often a preliminary stage to work in other media. Animation as a sequenced movement of colored images and texts with sounds. There are several types of film, one of them is animation movie, which is distinguished from live action ones by the unusual kinds of work that are done at the production stage. Animation films do not do continuously filming free action in the real time, but they create a series of images by shooting one frame at a time.

Vocabulary achievement intended for the learners to learn new words. The vocabulary achievement program facilities are learning additional words [6]. The vocabulary for achievement facilities broad vocabulary learning through the systematic teaching of strategies [7]. So the researcher concludes that vocabulary achievement is a program to facilitate learners to learn words through systematic teaching-learning strategies. Learning vocabulary is not a simple process. The learners are expected to recall the word and recognize it in spoken and written form. Vocabulary achievement requires the elaboration of meaning and pronunciation [8]. Meaning is the idea that a word represents, whereas pronunciation is the way in which a particular word is pronounced.

To improve learners' vocabulary, this study used animated video as media, which is expected to attract the learners' attention. Teaching and 
learning process for vocabulary subject using video as media is hypothesized to be an effective way to improve learners' vocabulary. Learners were asked to elaborate eagerly what they are watching and listening to comprehend the materials included in the animated video.

\section{MATERIALS AND METHOD}

\section{A. Materials}

The use of animated video as a media in teaching and learning vocabulary is one of the materials in this study comprises the independent variable in this study, and the dependent variable is the learners' vocabulary, all words that are used by people in oral and written communication in everyday life. Twenty Junior High school learners in Mataram, Indonesia was chosen randomly participated in this study. The other material is vocabulary test as a research instrument, which is administered both on pre-test and post-test. A pre-test is intended to find out the basic knowledge of the learners, and the test was given before doing the treatment. Then, post-test is intended to know the learners' vocabulary after giving treatment. In the pre-test, the respondents were given several kinds of test in the form of fill in the blank, synonym, antonym, and jumble words consisted of fifty items.

\section{B. Method}

This study employed pre-experimental research to investigate the use of animated video to improve the learner's vocabulary. The research design was one group pretest-posttest design. Treatment $(\mathrm{X})$ was given between pretest (O1) and posttest (O2) [9]. The procedure for collecting data was divided into three steps; those are pretest, treatment, and posttest. The pre-test was conducted to identify the learners' prior knowledge of vocabulary in the written test. The learners were asked to put the words in context, multiple choice, and jumble words. The learners were taught using animated video, and then the treatment was given for five meetings after conducting the pretest. The researchers also explained about vocabulary, kinds of vocabulary, and the procedure of the test. The video was different on each meeting. After watching the video, the learners were asked to write the ten to twelve words in the worksheet that they comprehended. After giving the treatment, the posttest were conducted to measure the vocabulary achievement after treatment. To analyze the data, the data gathered fifty items through vocabulary test in written form. The steps of the collecting data undertaken quantitatively by scoring the learners' answer, classifying the score of the learners [10] into five levels as in Table 1. 
TABLE I

CLASSIFICATION OF LEARNERS SCORE

\begin{tabular}{llll}
\hline \hline No. & Score & & Classification \\
\hline 1 & $3.51-4.00$ & $91-100$ & Very Good \\
2 & $2.51-3.50$ & $76-90$ & Good \\
3 & $1.51-2.50$ & $61-75$ & Fair \\
4 & $1.00-1.50$ & $51-60$ & Poor \\
5 & Less than 1.00 & $\leq 50$ & Very Poor \\
\hline \hline
\end{tabular}

After conducting the score classification above, the researcher found out the learners' mean score, calculating the standard deviation and t-test by using SPSS, and finding out the significant difference between pre-test and post-test by using SPPS.

\section{RESULTS AND DISCUSSION}

This section mainly presents the result and the elaboration through discussion of those data based on the study conducted. The result of the study consisted of the data collected through vocabulary test while the discussion covered the detail of result. This analysis describes detail explanation of the rate percentage of pre-test and post-test, mean score and standard deviation of learners' t-test was measured to investigate the significant use of the animated video to improve vocabulary of the learners. The percentage of the vocabulary achievement is shown in Figure 1 below.

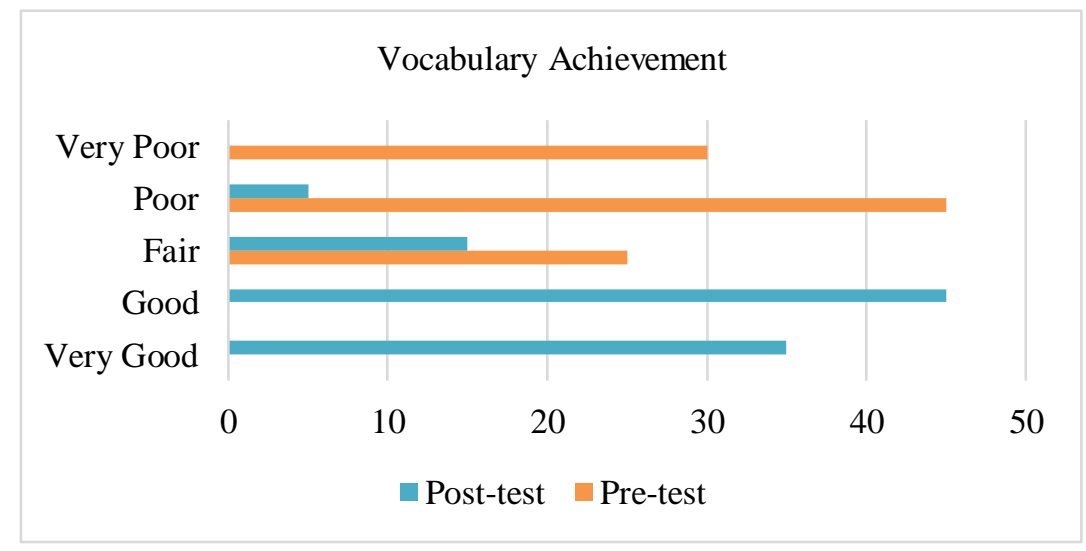

Fig. 1. Vocabulary Achievement

Figure 1 above indicates that none of the learners classified into very good and good in the pretest, but their percentage increased considerably in post-test to thirty-five percent learners on very good and forty-five percent on good. The percentage of learners in the fair category in pretest was twenty- 
five percent remained fifteen percent in post-test. The significant declined percentage of learners in poor and very poor category indicates the significant improvement of vocabulary achievement. Figure 1 above indicates that forty-five percent learners who were a poor category in pretest declined to only five percent in the pretest. Overall, the percentage of the vocabulary achievement of the junior high school who participated in this research increased significantly. Similarly, learners who were in very poor category declined considerably from thirty percent in pretest remained zero percent in post-test. The vocabulary achievement of the learners in this study was also measured using the mean score and standard deviation as in Table 2 below.

TABLE II.

MEAN SCORE AND STANDARD DEVIATION

\begin{tabular}{llllll}
\hline \hline \multicolumn{5}{c}{ DESCRIPTIVE STATISTICS } \\
\hline \multirow{2}{*}{ pre-test } & $\mathrm{N}$ & Minimum & Maximum & Mean & Std. Deviation \\
post test & 20 & 22 & 66 & 52.9 & 12.1 \\
Valid N (Listwise) & 20 & 50 & 96 & 84.5 & 11.6 \\
\hline \hline
\end{tabular}

Table 2 above describes the mean score of the pretest, which is 52.9 with standard deviation 12.1 while the mean score in posttest improves to 84.5 with standard deviation 11.6. It indicates that the learners' vocabulary achievement improves significantly after given the treatment by applying video as a media. This analysis also deals with the detailed explanation of the statistics on the correlation and the significant difference between pretest and posttest as in Table 3 below.

TABLE III.

PAIRED SAMPLE TEST

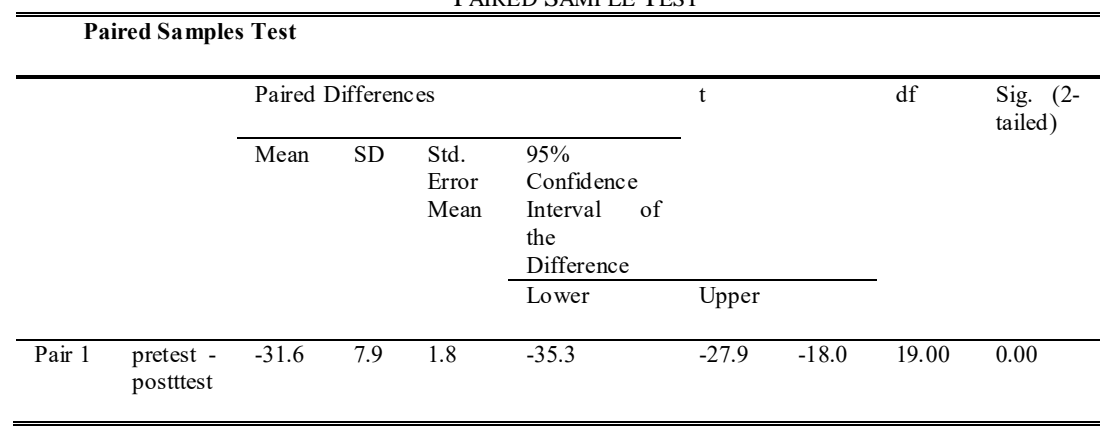

IJoASER, Volume 1, Issue 1, March 2018

DOI: 10.33648 /ijoaser.v1i1.5

Copyright: STAI Al-Furqan Makassar,Indonesia

Content License: CC-BY-SA 
Table 3 above shows the homogeneity of the sample in the pretest. It can be seen that the significance value $(0.00)$ is lower than 0.05 . The value of significance is lower than the level significance $(\alpha)=0.05$. This result conveys that alternative hypothesis (H1) is accepted. Based on the explanation above, this study indicates the use of video improves learners' vocabulary achievement. The data collected through vocabulary test, as explained, showed that the use of animated video as teaching media could improve learners' vocabulary achievement.

Based on the minimum criteria of English lesson for the junior high school, the learners are expected to get the minimum score of 75 . In fact, the result of pretest showed most of the learners could not achieve the score. By looking at the learners' pre-test, most of the learners were in fair and poor. While, the learners' post-test shows that the learners were classified into very good, good and fair. After giving pretest, this study provided treatment to the learners this study used animated video as teaching media during the treatment to improve learners' vocabulary achievement. The learners were asked to write the words, find the meaning and make a sentence based on the animated video.

During the treatment, the learners were interested in learning English to improve their vocabulary. It could be seen from the learners' scoring in pretest and posttest. The learners showed their vocabularies improvement in their sentences. This study indicates that the learners understood the meaning and can make a sentence of the words correctly in post-test. Thus, learners' problem in learning English which with lack of ideas, lack of vocabulary and have low interest in learning could be decreased by using video in teaching and learning activity due to the significant improvement of vocabulary achievement in this study.

This study found some several positive effects resulted from teaching learners how to learn new vocabulary. Firstly, the learners write down the words from the video; it can improve the learners' curiosity in learning new vocabulary. Secondly, the learners can remember the new vocabulary easily because the learners find the meaning of the words by themselves, write the words by themselves and make sentences by using the words.However, in the implementation of animated video as media in teaching vocabulary, some obstacles make the treatment did not run as planned before. The problems deal with time management, which is very important in teaching. Watching video took time and make learners want to watch, and forgot that they had learned using video and must answer the question.

This study revealed that animated videocould be a capable media and foundation of learning and foundation [11]. This study also can increase learners' motivation and interest to when they are learning a language using video [8]. Learners were challenged to express their opinion in the classroom when they were watching the animated videoduring the teaching and learning vocabulary. This study also indicates that students can create a link between mind, sight, and hearing which can help learners to achieve the information more accessible[1]. This study also indicates that learners got ideas and information from watching the video such as identify the events or phenomena, how to spell the words, they can identify the picture and the 
name of it from the video. Thus, the learners could explore their thought to make sentences; they knew what they had to write. The findings of this study go in line with some studies found that video as teaching media can help learners to improve vocabulary achievement [12]-[14].

\section{CONCLUSION}

This study found that the use of video as teaching media improves the vocabulary of the young learners considerably after being given treatments. It is proved by the value of significance 0.000 which was lower the level of significance $(\alpha)=0.05$. Mean score of post-test of 84.5 was higher than the mean score of the pre-test was in 52.9). One of the media in teaching English especially for learning vocabulary that can be recommended to the English teachers for young learners is using video to attract the learners to learn English vocabulary.In utilizing the animated video in the teaching-learning process, the teacher should be creative and innovative in teaching to challenge the learners to be more enjoyable.It is suggested to the further study to conduct a similar study using animated video as teaching media.

\section{REFERENCES}

[1] H. D. Brown and H. Lee, Teaching by Principles: An Interactive Approach to Language Pedagogy. Pearson Education, 2015.

[2] J. S. Decarrico, "Vocabulary learning and teaching," Teach. English as a Second or foreign Lang., vol. 3, pp. 285-299, 2001.

[3] V. S. Gerlach, D. P. Ely, and R. Melnick, Teaching and media: a systematic approach. Prentice Hall PTR, 1980.

[4] D. Cahyaningrum, "The effectiveness of using video in teaching listening of oral narrative text." Universitas Sebelas Maret, 2010.

[5] R. Awad, "The Effect of Using Animation in Teaching English Vocabulary for 3rd Graders in Gaza Governmental Schools," Unpubl. Master thesis), AL-Azhar Univ. Palest., 2013.

[6] M. A. Richek and G. Source, Vocabulary for Achievement: Fourth Course. Houghton Mifflin School, 2005.

[7] J. F. Baumann, E. C. Edwards, G. Font, C. A. Tereshinski, E. J. Kame'enui, and S. Olejnik, "Teaching morphemic and contextual analysis to fifth-grade students," Read. Res. Q., vol. 37, no. 2, pp. 150-176, 2002.

[8] J. Harmer, The Practice of English Language Teaching. Pearson Education, 2015.

[9] G. E. Mills and L. R. Gay, Educational Research: Competencies for Analysis and Applications. Pearson Education, 2018.

[10] Menteri Pendidikan dan Kebudayaan Republik Indonesia, "Peraturan Menteri Pendidikan dan Kebudayaan Republik Indonesia nomor 104, tahun 2014, tentang penilaian hasil belajar oleh pendidik pada pendidikan dasar dan pendidikan menengah," Peraturan menteri pendidikan dan kebudayaan Republik Indonesia. 2014.

[11] R. M. Gagne, "Learning Theory, Educational Media, and Individualized Instruction.," 1970 .

[12] F. Munir, "The effectiveness of teaching vocabulary by using cartoon film toward vocabulary mastery of EFL students," J. English Lang. Teach. Linguist., vol. 1, no. 1, pp. 13-37, 2016.

[13] M. J. Kennedy, W. J. Rodgers, J. E. Romig, J. W. Lloyd, and M. T. Brownell, "Effects of a multimedia professional development package on inclusive science teachers' vocabulary instruction," J. Teach. Educ., vol. 68, no. 2, pp. 213-230, 2017. 
[14] I. Elgort, "Teaching/Developing Vocabulary Using ICTs and Digital Resources," TESOL Encycl. English Lang. Teach., 2018. 